\title{
Düzce Kenti Yaya Bölgelerinin Gürültü Farklarının İncelenmesi
}

\author{
Özgür YERLİ \\ Düzce Üniversitesi, Orman Fakültesi, Peyzaj Mimarlığı Bölümü, 81620, Düzce/TÜRKIYE \\ Sorumlu yazar: ozguryerli@gmail.com
}

Geliş Tarihi: 07.02.2016

\begin{abstract}
Özet
Gürültti günümüzde özellikle metropol kentlerde en temel çevre sorunlarından biri haline gelmiştir. Gürültünün insan sağlığını tehdit ettiği ve kentsel kaliteyi azalttığı bilinmektedir. Yaya bölgelerinin kalitesi de kentlerin gelişmişlik düzeylerinin bir göstergesi olarak kabul edilmektedir. Bu çalışmada Düzce Kenti'nde üç farklı kentsel alan kullanımı içinde bulunan (konut bölgesi, açık ve yeşil alan, ticaret) dört yaya bölgesinin (Pazar Yeri, Anıtpark, Spor Sokak, Gaziantep Caddesi) gürültü miktarları arasındaki farklar incelenmiştir. Gürültü ölçümleri Svan Svantek 957 gürültü ölçüm cihazı ile bir yıl boyunca gerçekleştirilmiştir. Elde edilen veriler yaya bölgeleri ile aylar arası ilişkiler ve alan kullanımı ile gürültü miktarı arasındaki ilişkiler açısından istatistiksel olarak incelenmiş, anlamlı farkların açıklanabilmesi için Anova ve Tukey testlerinden faydalanılmıştır. Sonuç olarak yaya bölgelerinde yaz aylarında gürültü miktarının arttığı buna karşılık kış aylarında en az gürültünün oluştuğu bulunmuştur. Kentsel alan kullanımı ve gürültü arasındaki ilişkiye göre ise ticaret alanlarında yer alan yaya bölgelerinin daha gürültülü, konut alanlarında yer alan yaya bölgelerinin ise daha sessiz oldukları sonucuna ulaşılmıştır. Gürültü miktarları, Çevresel Gürültünün Değerlendirilmesi ve Yönetimi Yönetmeliği'ne göre değerlendirilmiş̧tir.
\end{abstract}

Anahtar kelimeler: Gürültü, yaya bölgesi, Düzce, alan kullanım türü.

\section{Investigation of Noise Differences of Pedestrian Zones in Düzce City}

\begin{abstract}
Nowadays noise has become one of the most fundamental environmental issues, especially in metropolitan cities. It is known that noise is a threat for human health and it reduce the urban quality. The quality of the pedestrian areas of the cities can also be considered as an indicator of the level of development. In this study the differences among the amount of noise of four pedestrian areas (bazaar place, Anitpark, Spor Street, Gaziantep Street) were examined which located on three different urban areas (residential area, open and green spaces, commercial) in the city of Düzce. Noise measurements were carried out throughout a year with Svan Svantek 957 noise meter. The data is evaluated statistically in terms of the relation between the pedestrian zones and months and the relation between land use type and the amount of noise. ANOVA and Tukey tests have been utilized to explain the significant differences. As a result it is found that the amount of noise increases in summer months whereas the least noise occurs in winter months. It is reached the conclusion the pedestrian areas that located in commercial zone were more noisy but located in residential areas were more quiet. Noise amount was evaluated according to Regulation of Evaluation and Management of Environmental Noise.
\end{abstract}

Keywords: Noise, pedestrian zone, Düzce, land use type.

\section{Giriş}

Çevre sorunları insanoğlunun var olduğu andan itibaren ortaya çıkmış, zaman içerisinde gelişen teknoloji ile birlikte büyüyen kentler, artan ihtiyaçlar eşliğinde kendini daha s1k ve farklı alanlarda hissettirmeye başlamıştır. Hava, su, toprak gibi temel çevre sorunlarının yanında son yıllarda gürültü kirliliği de çevre sorunları arasında sayılmaya başlanmıştır. Günümüzde ise gürültü artık insanoğlunu günlük yaşantısında rahatsız eden ve hatta sağlığını tehlikeye sokan bir unsur haline gelmiştir (Bayramoğlu ve ark., 2014). Yapılan çalışmalar kentlerdeki gürültü kirliliğinin en fazla trafikten kaynaklandığını göstermektedir (Salomons ve Pont, 2012; Szeremeta ve Zannin, 2008; Yerli, 2012; Doygun ve Gurun, 2008; Ko ve ark., 2011; Pathak ve ark., 2008). İnsanların beden ve ruh sağlı̆̆ 1 üzerinde kötü etkileri bulunan gürültü, sadece büyükşsehirlerde değil hemen hemen bütün yerleşme merkezlerinde bir sorun olmaktadir (Ural, 2008). 
Gürültü, gürültünün zararları ve tedbirler konularını içeren ilk yönetmelik, 11 Aralık 1986 tarihli 19380 sayılı Resmi Gazete'de yayımlanan "Gürültü Kontrol Yönetmeliği”dir. $\mathrm{Bu}$ yönetmeliğin amac1, kişilerin huzur ve sükûnunu beden ve ruh sağlığını gürültü ile bozmayacak bir çevrenin geliştirilmesini sağlamaktır. Yönetmelik, bu amaca uygun olarak gürültü ile ilgili terimlerin tarifi ile gürültü kontrolünün uygulanacağ ${ }_{1}$ sinırların belirlenmesi esaslarını kapsamaktadır.

Yaya bölgeleri, kent merkezlerinde araç trafiğinin yasaklandığı ya da çeşitli hizmet ve servisler için belli saatlerde araç giriş çıkışına izin verildiği, tamamen yayaların kullanımına ayrılmış bölgelerdir. $\mathrm{Bu}$ özellikleri sebebi ile aslında yaya bölgeleri insanlar arası iletişimin arttı̆̆1 ve kentsel kültüre olumlu yönde katk1 sağlandığ alanlardır (Şişman ve Uyguner, 2009). Yaya bölgeleri insanlar tarafından yoğunlukları farklı da olsa günün her saatinde kullanılmaktadır. Meydanlar, pazar yerleri, yaya trafiğgine açık olan cadde ve sokaklar bu alanlara örnek olarak verilebilmektedir. Bu tip alanlarda oluşacak gürültünün miktarı da yaya bölgesinin kullanım tipi, mevsim, günün saati, atmosfer koşulları gibi çeşitli şartlara bağlı olarak değişebilmektedir.

$\mathrm{Bu}$ çalışmanın amacı Düzce Kenti'nde bulunan yaya bölgelerinin gürültü miktarlarını tespit etmek, gürültü miktarları arasındaki farkların ölçümlerin yapıldığı aylar ve yaya bölgelerinin bulunduğu kentsel alan kullanım tipleri ile ilişkisini araştırmaktır. Düzce kenti yaya bölgelerindeki gürültü miktarlarını araştıran bir çalışmanın daha önce yapılmamıs olması, araștırmanın önemini ve literatüre olan katkısını arttırmaktadır. Çalışmanın sonunda doğruluğu ispatlanmaya çalışılan hipotezler şu şekilde sıralanabilmektedir:

- Aylara göre yaya bölgelerinde tespit edilen gürültü miktarları arasındaki farklar anlamlidir,

- Yaya bölgelerinde tespit edilen gürültü miktarları arasındaki farklar, yaya bölgelerinin bulunduğu kentsel alan kullanımları ile ilişkilidir.

$\mathrm{Bu}$ amaca yönelik olarak bir yıl boyunca her hafta düzenli olarak yaya bölgelerinden gürültü ölçümleri yapılmış, elde edilen bulgular aylik ve mevsimlik ortalamalara dönüştürülmüştür. Elde edilen veriler istatistiksel olarak analiz edilmiş ve anlamlı bulunan gürültü farkları bölgelerin mevcut alan kullanımları dikkate alınarak yorumlanmıştır.

\section{Materyal Ve Yöntem \\ Çalışma Alanı}

Düzce il merkezi $40^{\circ} 40^{\prime}-40^{\circ} 47^{\prime}$ kuzey enlemi ile, $31^{\circ} 21^{\prime}-31^{\circ} 26^{\prime}$ doğu boylamında, Bolu ili topraklarının batı ve kuzeyinde, Sakarya ilinin doğusunda ve Zonguldak ilinin güneybatısında yer almaktadır. Kuzeyinde Karadeniz ile sinırdır. Şekil 1'de Düzce'nin Türkiye sinırları içindeki yeri ve çalışma alanını oluşturan Düzce Belediye sınırlarının Düzce il sınırları içindeki konumu verilmiştir. $\mathrm{Bu}$ çalışma kapsamında belirlenen alan sinırları ise Düzce Belediye sınırlarıdır.

Şekil 2'de ise Düzce Kenti Mevcut Arazi Kullanım Haritası görülmektedir. Bu haritaya göre kahverengiye boyalı konut bölgelerinin özellikle şehir merkezinde ve kentin kuzeydoğusunda yer alan Yenikent bölgesinde ağırlıklı olarak yer aldığ1 görülmektedir. Ticaret alanlarını kırmızıya boyalı bölgeler oluşturmaktadır. Bu bölgeler kent merkezinde özellikle ulaşımı sağlayan ana arterler üzerinde sağlı sollu dizilim göstermektedirler. Sanayi bölgelerinin en yoğun hissedildiği alanlar, kent merkezine D100 karayolu üzerinde bulunan eski ve yeni sanayi çarşılarının olduğu kısımlardır. Bunun dışında çeșitli ölçekteki birçok fabrika da yine D-100 karayolu üzerinde özellikle Çoban Kavşağı'nın doğusunda Ankara istikametinde konumlanmıștır. Yeșil alanlar kent merkezinde yok denecek kadar az, buna karşın kentin kuzeydoğusunda konumlanan Yenikent alanında konut alanları ile dengeli bir dağılım göstermektedir. Çalışma kapsamında ele alınan yaya bölgeleri, konut, ticaret ve yeşil alan kullanımlarında yer almaktadır. Düzce'de sanayi alanlarında yaya bölgesi bulunmamaktadır.

\section{Materyal}

Calıșmanın temel materyali Düzce kentinde yer alan Pazar Yeri, Anıtpark, Spor Sokak ve Gaziantep Caddesi Yaya Bölgeleri'dir. Yılın belli günlerinde çeşitli etkinlikler için yayalaștırılan alanlar dıșta 
tutulursa bu dört bölge dışında Düzce kentinde yaya bölgesi bulunmamaktadır. Çalışma alanlarının bulunduğu bölgeler arazi kullanım haritasında incelendiğinde Pazar Yeri'nin ağırlıklı olarak konut bölgesi, Anıtpark'ın açık ve yeşil alan, Spor Sokak ve Gaziantep Caddesi'nin ise ticaret alanı olduğu görülmektedir. Yani dört farklı yaya bölgesi üç farklı alan kullanımı altında toplanmıştır. $\mathrm{Bu}$ durum çalışmanın sonuçlarına zenginlik katacak bir değer olarak yorumlanmaktadır.

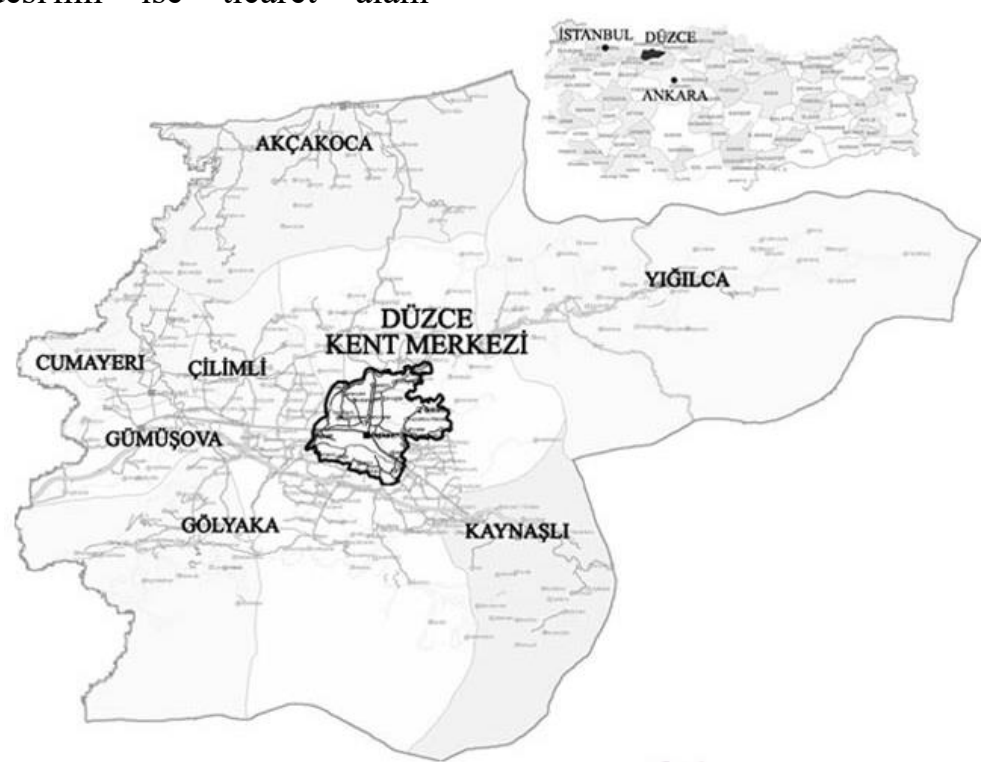

Şekil 1. Düzce Belediye sınırlarının Düzce il sınırları içindeki konumu

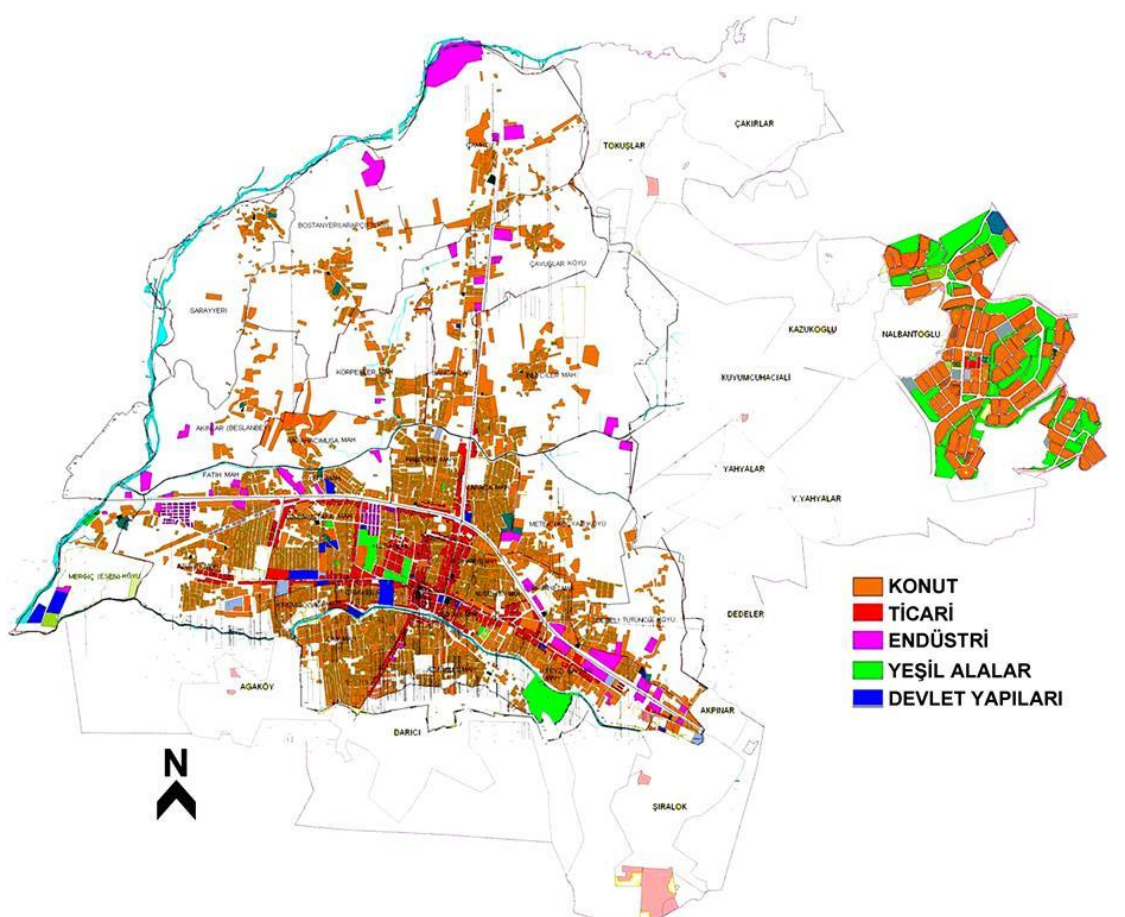

Şekil 2. Düzce Kenti arazi kullanım haritası

Düzce kenti imar planı, Düzce kenti arazi kullanım haritası, çalışma alanlarından çekilen fotoğraflar, gürültü ölçümü için kullanılan Svan marka Svantek 957 gürültü ölçüm cihazı, istatistik analizler için kullanılan SPSS 15 programı, konu ile ilgili ulusal ve uluslararası literatür verileri bu çalışmada kullanılan materyaller arasındadır. 


\section{Yöntem}

Yöntemin temeli gürültü ölçümlerinin yapılması ve yaya bölgelerindeki gürültü miktarlarının tespitine dayanmaktadır. $\mathrm{Bu}$ amaca yönelik olarak 2014 yılı mart ayı ve 2015 y1lı şubat ayı aralığını kapsayan bir yıl içerisinde her hafta gürültü ölçümleri yapılmıştır. Gürültü ölçümleri, çizgisel bir hat niteliğindeki Pazaryeri'nde birbirine yaklaşık olarak eşit uzaklıkta 6, Spor Sokak ve Gaziantep Caddesi üzerinde yine birbirine yaklaşık olarak eşit uzaklıkta 3 noktada, Anıtpark'ta ise alan içerisinde 4 noktada 10'ar dakika boyunca, Çevresel Gürültünün Değerlendirilmesi ve Yönetimi Yönetmeliği'ne (URL1, 2016) göre gündüz saatlerinde yapılmıştır. Bayramoğlu ve ark., (2014), Güremen (2012), Kang and Zhang (2010) yaptıkları çalışmalarda sırası ile 3, 3 ve 1 dakikalık ölçümler yapmışlardır. Gürültü ölçüm süresinin uzun olmasının ve ölçüm alınan nokta sayısının fazlalığının, sonucun güvenilirliğini $\operatorname{arttırdığ1~}$ bilinmektedir (Anonim 2012). Bu çalışmada her ölçüm süresinin 10 dakika üzerinden yapılması ile çalışmanın güvenilirliğinin arttırılması hedeflenmiștir. Ölçüm yapılan alanlarda farklı sayıda ölçüm noktasının belirlenmesinin nedeni ise alanların farklı uzunluklarla olmasıdır. Pazar Yeri, Spor Sokak ve Gaziantep Caddesi doğrusal nitelikte alanlar olduğu için bu örneklerde yaklaşık olarak 100 metrede bir ölçüm noktası tayin edilmiştir.

Haftaiçi, haftasonu, günün farklı saatleri gibi koşullar nedeniyle ölçümler sırasında oluşacak farklılıkları en aza indirebilmek için ölçümlerin eşdeğer koşullarda yapılmasına özen gösterilmiştir. Elde edilen değerler aylık ve mevsimlik ortalamalara dönüştürülmüştür. Farklı yaya bölgelerine ait elde edilen gürültü miktarlarının karşılaştırılması amacıyla istatistiksel analizler yapılmıştır. Gürültü miktarları arasındaki anlamlı farkların tespiti için Anova analizi uygulanmış, farkların detaylıca açıklanabilmesi için Tukey seçeneğinden yararlanılmıştır. Aynı analiz alan kullanımı ve bu alanlardaki gürültü miktarlarının karşılaştırılması için de uygulanmıştır. Sonuçlar yaya bölgelerinin alan kullanımları ile ilişkilendirilerek yorumlanmıştır. Varyans analizi iki ya da daha fazla gruba ait ortalamalar arasındaki farkın anlamlı olup olmadığı ile ilgili hipotezlerin test edilmesi amaciyla kullanılmaktadır (Ural ve Kılıç 2005; Altunışık ve ark. 2010). Yerli ve Demir (2015), Yerli ve diğ. (2013), Kang and Zhang (2010), Livera ve ark. (2008), Lüleci (2000) yaptıkları çalışmalarda gürültü miktarlarını istatistiksel olarak analiz etmişler, bu çalışmada olduğu gibi farklı gruplara ait aynı değişkenin ortaya koyduğu farkları açılayabilmek için ANOVA analizinden yararlanmışlardır. Ayrıca, Özyonar ve Peker (2008), Şahin (2007), Uslu ve diğ. (2007), Deveci (2004) bu çalıșmadakine benzer bir şekilde farklı kentsel alan kullanım tiplerinde gürültü miktarlarının tespitine yönelik çalışmalar yapmışlardır.

Gürültü miktarlarının karşılaştırılması hem yaya bölgelerinde ölçülen değerler arasında hem de Çevresel Gürültünün Değerlendirilmesi ve Yönetimi Yönetmeliği'nde verilen değerlere göre yapılmıştır. Buna göre ticari yapılar ile gürültüye hassas kullanımların birlikte bulunduğu alanlardan, konutların yoğun olarak bulunduğu alanlarda izin verilen değerler onarılmış yollarda $63 \mathrm{~dB}(\mathrm{~A})$, mevcut yollarda ise $68 \mathrm{~dB}(\mathrm{~A})$ 'dır. Ticari yapılar ile gürültüye hassas kullanımların birlikte bulunduğu alanlardan, işyerlerinin yoğun olarak bulunduğu alanlarda izin verilen değerler ise onarılmış yollarda $65 \mathrm{~dB}(\mathrm{~A})$, mevcut yollarda ise $70 \mathrm{~dB}(\mathrm{~A})$ 'dır.

\section{Bulgular}

Pazar yeri yaya bölgesi, Düzce kenti Aziziye Mahallesinde yer almaktadır. İki tarafi araç yolu olan yaklaşık 750 metre uzunluğunda ve 30 metre genişliğinde bir yaya bölgesi niteliğindedir. İnce ve uzun bir hat özelliğinde olan bu yaya bölgesi yer yer araç yolları ile kesilmektedir. Pazar yerinin konumu ve alandan fotoğraflar Şekil 3 'te verilmiştir. Pazar yeri yaya bölgesinin bulunduğu alan, arazi kullanım haritasına göre konut yerleşimidir. Pazar yerinde yapılan gürültü ölçümlerinde en yükssek ortalama değer $70.2 \mathrm{~dB}(\mathrm{~A})$ ile ağustos, en küçük ortalama değer ise $55.6 \mathrm{~dB}(\mathrm{~A})$ ile aralık ayında ölçülmüştür. 
Aylara göre yapılan değerlendirmede pazar yeri için en yüksek ortalama 69.95 $\mathrm{dB}(\mathrm{A})$ değeri ile ağustos, $59.3 \mathrm{~dB}(\mathrm{~A})$ değeri ile mart ayında hesaplanmıştır. Mevsimlere göre değerlendirme yapıldığında ortalama gürültü değeri yüksekten düşüğe doğru sırasıyla kış mevsiminde $60.35 \mathrm{~dB}(\mathrm{~A})$, ilkbahar mevsiminde $63.8 \mathrm{~dB}(\mathrm{~A})$, sonbahar mevsiminde $65.35 \mathrm{~dB}(\mathrm{~A})$ ve yaz mevsiminde $67.95 \mathrm{~dB}(\mathrm{~A})$ olarak hesaplanmıştır.

Anıtpark yaya bölgesi, Düzce kenti Kültür Mahallesinde yer almaktadır. Bu alan aynı zamanda resmi tören, konser, festival, toplantı, gösteri gibi çeşitli dış mekan etkinliklerinin de yapıldığı, yaklaşık olarak $8000 \mathrm{~m}^{2}$ büyüklügünde Düzce'nin tek kent meydanı niteliğindedir. Anıtpark'ın konumu ve alandan fotoğraflar Şekil 3 'te verilmiştir.

Anitpark yaya bölgesinin bulunduğu alan,

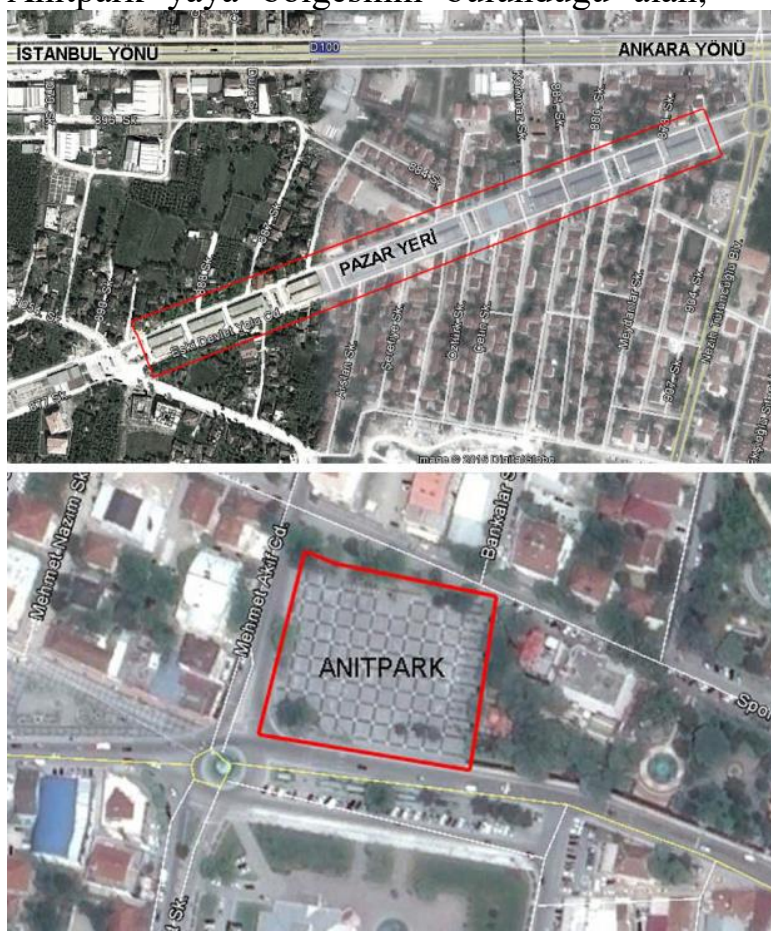

Şekil 3. Pazar Yeri ve Anıtpark

Spor Sokak yaya bölgesi, Düzce kenti Kültür Mahallesinde yer almaktadır. Doğu bat1 aksında yer alan Spor Sokak 10 metre genişliğinde ve yaklaşık olarak 550 metre uzunluğunda olmakla birlikte yayalara ayrılmış bölümünün uzunluğu 150 metre civarındadır. Spor Sokak yaya bölgesi 3-4

katlı yapıların çevrelediği bir ticaret aks1 olarak göze çarpmaktadır. Konut yerleșimi bulunmamaktadır. Yaya bölgesinin konumu ve alandan fotoğraflar Şekil 4'te verilmiștir. Spor Sokak yaya bölgesinin bulunduğu alan, arazi kullanım haritasına göre açık ve yeşil alan özelliğindedir. Anıtpark'ta yapılan gürültü ölçümlerinde en yüksek ortalama değer $68.4 \mathrm{~dB}(\mathrm{~A})$ ile ağustos, en küçük ortalama değer ise $56.5 \mathrm{~dB}(\mathrm{~A})$ ile ocak ayında ölçülmüştür.

Aylara göre yapılan değerlendirmede Anıtpark için en yüksek ortalama 66.75 $\mathrm{dB}(\mathrm{A})$ değeri ile ağustos, $58.3 \mathrm{~dB}(\mathrm{~A})$ değeri ile aralık ayında hesaplanmıștır. Mevsimlere göre değerlendirme yapıldığında ortalama gürültü değeri yüksekten düşüğe doğru sırasıyla kış mevsiminde $59.25 \mathrm{~dB}(\mathrm{~A})$, sonbahar mevsiminde $62.76 \mathrm{~dB}(\mathrm{~A})$, ilkbahar mevsiminde $63.5 \mathrm{~dB}(\mathrm{~A})$ ve yaz mevsiminde $64.71 \mathrm{~dB}(\mathrm{~A})$ olarak hesaplanmıştır.
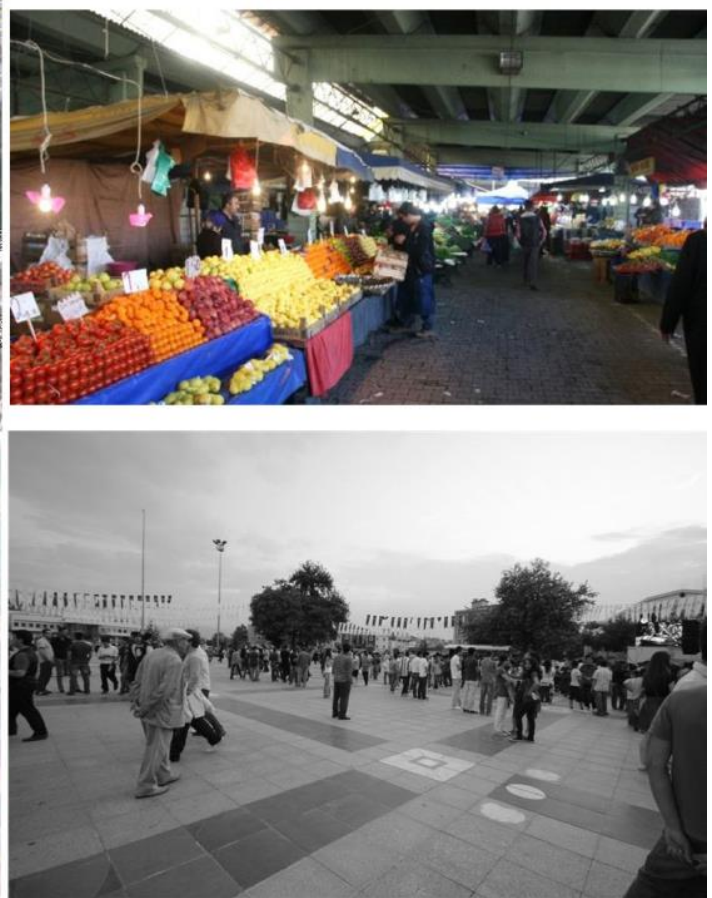

Yaya Bölgeleri (URL2, 2016)

arazi kullanım haritasına göre ticaret alanı özelliğindedir. Spor Sokak'ta yapılan gürültü ölçümlerinde en yüksek ortalama değer 72.8 $\mathrm{dB}(\mathrm{A})$ ile mayıs ve temmuz, en küçük ortalama değer ise $60.3 \mathrm{~dB}(\mathrm{~A})$ ile aralık ayında ölçülmüştür.

Aylara göre yapılan değerlendirmede Spor Sokak için en yüksek ortalama 72.15 $\mathrm{dB}(\mathrm{A})$ değeri ile temmuz, $61.0 \mathrm{~dB}(\mathrm{~A})$ değeri ile aralık ayında hesaplanmıştır. Mevsimlere göre değerlendirme yapıldığında ortalama gürültü değeri yüksekten düşüğe doğru 
sırasıyla kış mevsiminde $63.48 \mathrm{~dB}(\mathrm{~A})$, sonbahar mevsiminde $64.31 \mathrm{~dB}(\mathrm{~A})$, ilkbahar mevsiminde $70.41 \mathrm{~dB}(\mathrm{~A})$ ve yaz mevsiminde $70.94 \mathrm{~dB}(\mathrm{~A})$ olarak hesaplanmıştır.

Gaziantep Caddesi yaya bölgesi, Düzce kenti Kültür Mahallesinde yer almaktadır. Spor Sokak gibi doğu batı aksında yer alan Gaziantep Caddesi 20 metre genişliğinde ve yaklaşık olarak 170 metre uzunluğunda bir yaya bölgesidir. Gaziantep Caddesi yaya bölgesi Spor Sokak yaya bölgesinde olduğu gibi 3-4 katlı yapıların çevrelediği bir ticaret aks1 olarak göze çarpmaktadır. Konut yerleșimi bulunmamaktadır. Yaya bölgesinin konumu ve alandan fotoğraflar Şekil 4'te verilmiştir. Gaziantep Caddesi yaya bölgesinin bulunduğu alan, arazi kullanım haritasında ticaret alanı olarak görülmektedir. Gaziantep Caddesi'nde yapılan gürültü ölçümlerinde en yüksek ortalama değer 73.4 $\mathrm{dB}(\mathrm{A})$ ile temmuz, en küçük ortalama değer ise $59.2 \mathrm{~dB}(\mathrm{~A})$ ile aralık ayında ölçülmüştür.

Aylara göre yapılan değerlendirmede Gaziantep Caddesi için en yüksek ortalama $71.75 \mathrm{~dB}(\mathrm{~A})$ değeri ile temmuz, $60.1 \mathrm{~dB}(\mathrm{~A})$ değeri ile şubat ayında hesaplanmıştır. Mevsimlere göre değerlendirme yapıldığında ortalama gürültü değeri yüksekten düşüğe doğru sırasıyla kış mevsiminde $61.91 \mathrm{~dB}(\mathrm{~A})$, sonbahar mevsiminde $63.78 \mathrm{~dB}(\mathrm{~A})$, ilkbahar mevsiminde $68.46 \mathrm{~dB}(\mathrm{~A})$ ve yaz mevsiminde $71.18 \mathrm{~dB}(\mathrm{~A})$ olarak hesaplanmıştır.
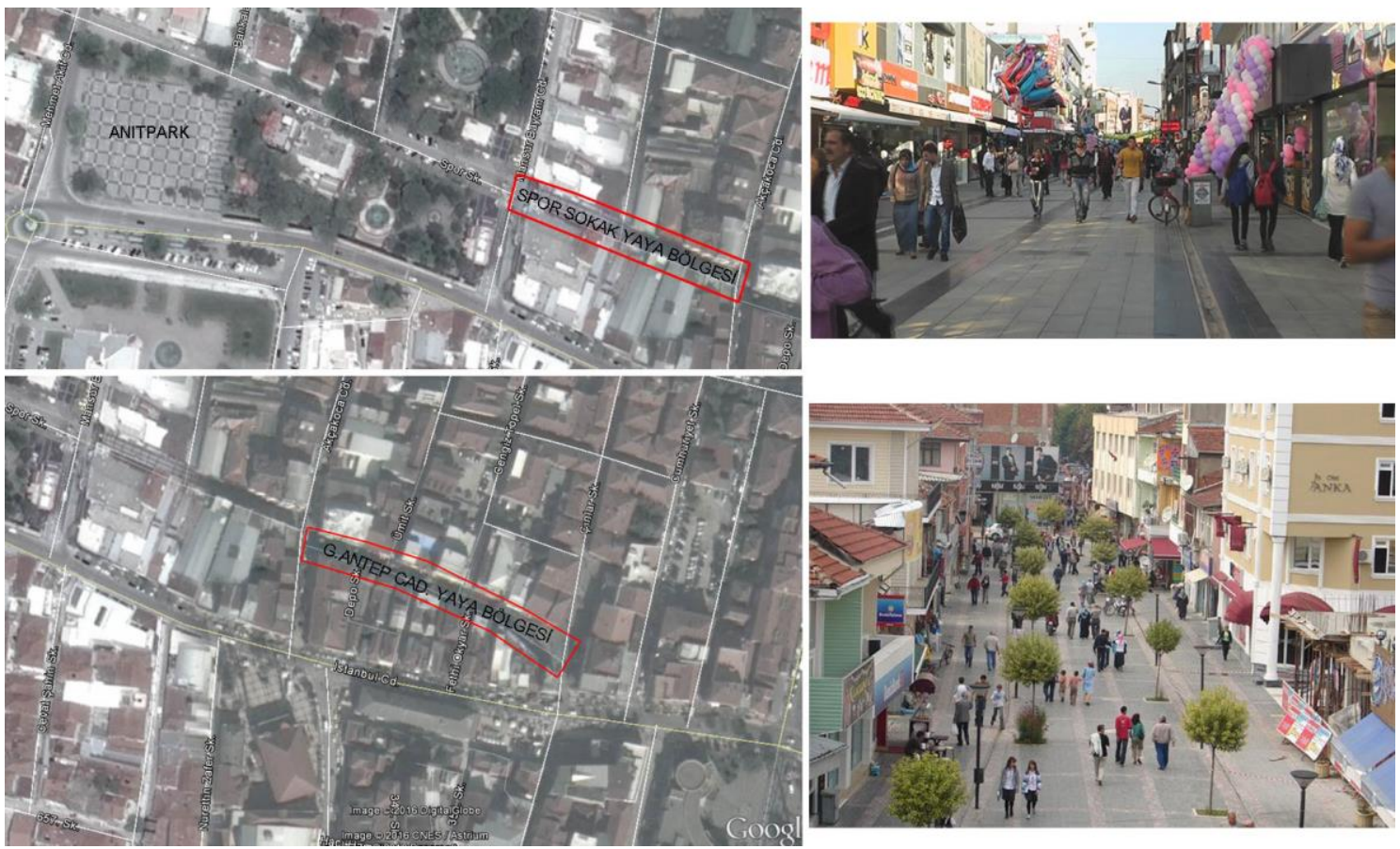

Şekil 4. Spor Sokak ve Gaziantep Caddesi Yaya Bölgeleri (URL1, 2016)

Yapılan ölçüm sonuçlarına ilişkin dört yaya bölgesinin aylık gürültü ortalamaların yer aldığ 1 grafik Şekil 5'te verilmiştir. Grafikten ve elde edilen verilerden anlaşılacağı üzere en sessiz ayların kış ayları olduğu görülmüştür. İlkbahar aylarında gürültü miktarı artmakta yaz aylarında en yüksek seviyelerde görülmekte ve sonbaharla beraber düşüşe geçmektedir. 


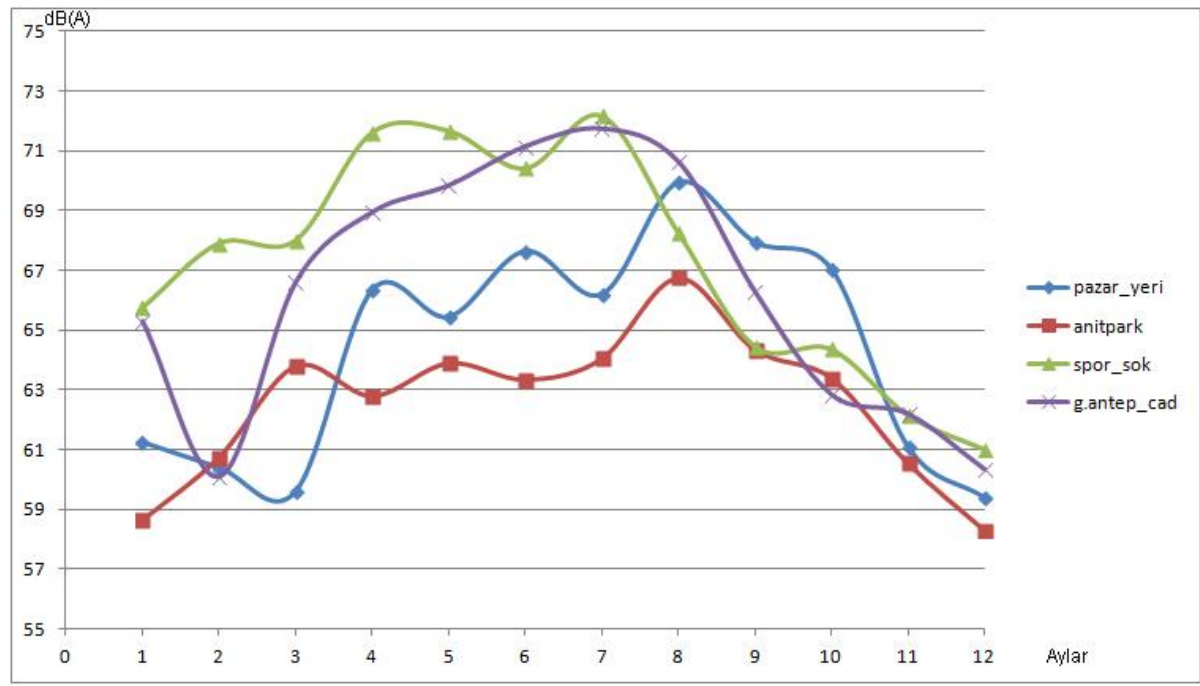

Şekil 5. Aylara göre yaya bölgelerindeki gürültü ortalamaları

Elde edilen sonuçlara göre ortaya çıkan farkların arasındaki ilişkilerin incelenmesi amaciyla veriler, istatistiksel olarak analiz edilmiştir. Her ay için elde edilen ortalama gürültü miktarları arasında, dört farklı yaya bölgesi açısından ortaya çıkan farkların

Tablo 1. Aylara göre yaya bölgelerindeki gürültü ortalamaları $(\mathrm{p}<0.05)$

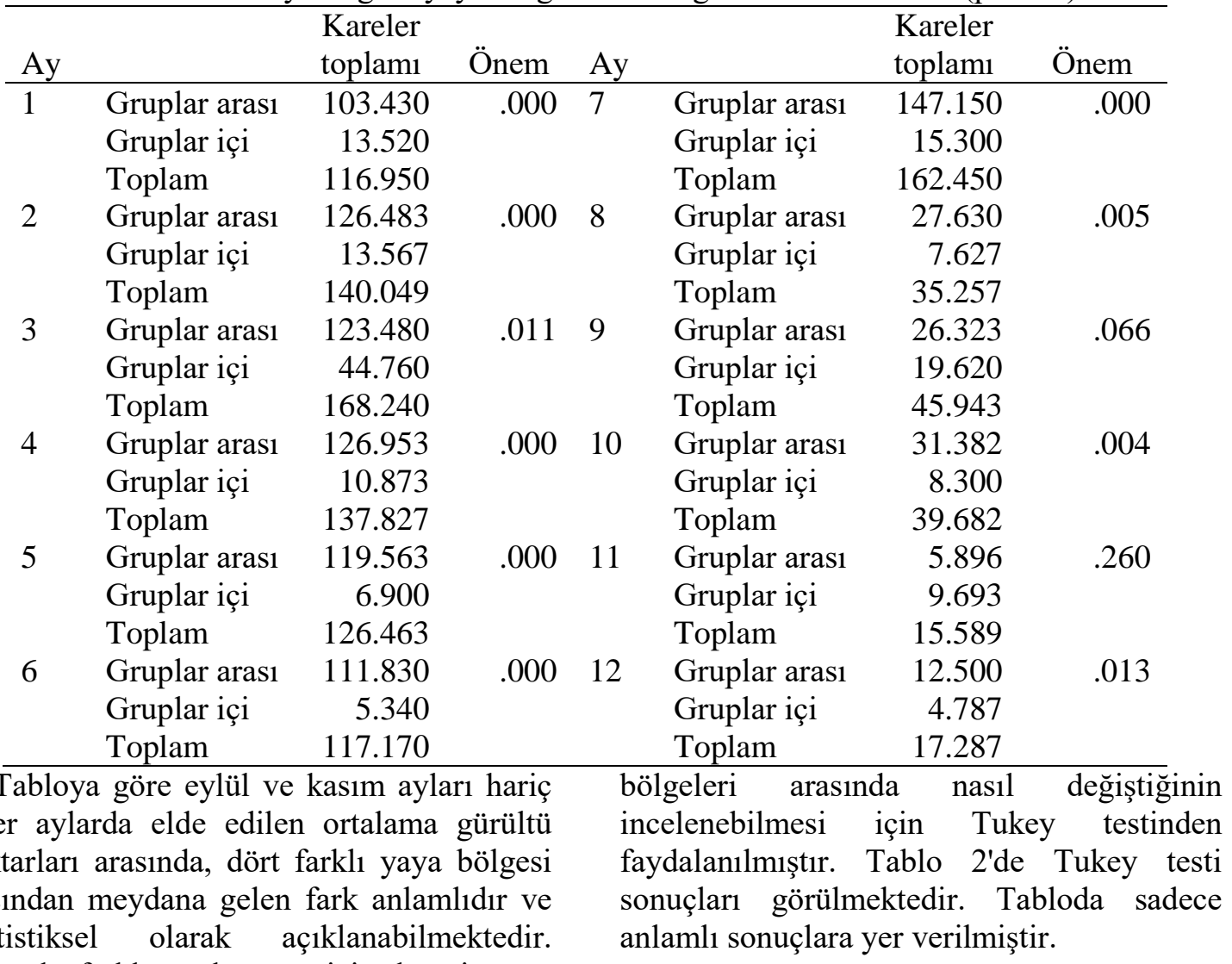


Tablo 2. Aylara göre yaya bölgelerindeki gürültü farkları $(\mathrm{p}<0.05)$

\begin{tabular}{|c|c|c|c|c|}
\hline $\begin{array}{l}\text { Bağımlı } \\
\text { değişken }\end{array}$ & $\begin{array}{l}\text { (I) Yaya } \\
\text { bölgesi }\end{array}$ & $\begin{array}{l}\text { (J) Yaya } \\
\text { bölgesi }\end{array}$ & $\begin{array}{r}\text { Ortalama Fark } \\
(\mathrm{I}-\mathrm{J})\end{array}$ & Önem \\
\hline \multirow[t]{8}{*}{ Ocak } & \multirow[t]{2}{*}{ Pazar Yeri } & Spor Sokak & $-4.50000(*)$ & .012 \\
\hline & & Gaziantep Cad. & $-4.03333(*)$ & .022 \\
\hline & \multirow[t]{2}{*}{ Anitpark } & Spor Sokak & $-7.10000(*)$ & .000 \\
\hline & & Gaziantep Cad. & $-6.63333(*)$ & .001 \\
\hline & \multirow[t]{2}{*}{ Spor Sokak } & Pazar Yeri & $4.50000(*)$ & .012 \\
\hline & & Anıtpark & $7.10000(*)$ & .001 \\
\hline & \multirow[t]{2}{*}{ Gaziantep Cad. } & Pazar Yeri & $4.03333(*)$ & .022 \\
\hline & & Anıtpark & $6.63333(*)$ & .001 \\
\hline \multirow[t]{6}{*}{ Şubat } & Pazar Yeri & Spor Sokak & $-7.50000(*)$ & .000 \\
\hline & Anıtpark & Spor Sokak & $-7.13333(*)$ & .001 \\
\hline & \multirow[t]{3}{*}{ Spor Sokak } & Pazar Yeri & $7.50000(*)$ & .000 \\
\hline & & Anitpark & 7.13333(*) & .001 \\
\hline & & Gaziantep Cad. & $7.80000(*)$ & .000 \\
\hline & Gaziantep Cad. & Spor Sokak & $-7.80000(*)$ & .000 \\
\hline \multirow[t]{4}{*}{ Mart } & \multirow[t]{2}{*}{ Pazar Yeri } & Spor Sokak & $-8.40000(*)$ & .010 \\
\hline & & Gaziantep Cad. & $-7.00000(*)$ & .028 \\
\hline & Spor Sokak & Pazar Yeri & $8.40000(*)$ & .010 \\
\hline & Gaziantep Cad. & Pazar Yeri & $7.00000(*)$ & .028 \\
\hline \multirow[t]{8}{*}{ Nisan } & \multirow[t]{2}{*}{ Pazar Yeri } & Anıtpark & $3.56667(*)$ & .023 \\
\hline & & Spor Sokak & $-5.23333(*)$ & .003 \\
\hline & \multirow[t]{3}{*}{ Anitpark } & Pazar Yeri & $-3.56667(*)$ & .023 \\
\hline & & Spor Sokak & $-8.80000(*)$ & .000 \\
\hline & & Gaziantep Cad. & $-6.16667(*)$ & .001 \\
\hline & \multirow[t]{2}{*}{ Spor Sokak } & Pazar Yeri & $5.23333(*)$ & .003 \\
\hline & & Anıtpark & $8.80000(*)$ & .000 \\
\hline & Gaziantep Cad. & Anitpark & $6.16667(*)$ & .001 \\
\hline \multirow[t]{8}{*}{ May1s } & \multirow[t]{2}{*}{ Pazar Yeri } & Spor Sokak & $-6.20000(*)$ & .000 \\
\hline & & Gaziantep Cad. & $-4.40000(*)$ & .002 \\
\hline & \multirow[t]{2}{*}{ Anitpark } & Spor Sokak & $-7.76667(*)$ & .000 \\
\hline & & Gaziantep Cad. & $-5.96667(*)$ & .000 \\
\hline & \multirow[t]{2}{*}{ Spor Sokak } & Pazar Yeri & $6.20000(*)$ & .000 \\
\hline & & Anıtpark & $7.76667(*)$ & .000 \\
\hline & \multirow[t]{2}{*}{ Gaziantep Cad. } & Pazar Yeri & $4.40000(*)$ & .002 \\
\hline & & Anıtpark & $5.96667(*)$ & .000 \\
\hline \multirow[t]{10}{*}{ Haziran } & \multirow[t]{3}{*}{ Pazar Yeri } & Anitpark & $4.30000(*)$ & .001 \\
\hline & & Spor Sokak & $-2.73333(*)$ & .015 \\
\hline & & Gaziantep Cad. & $-3.50000(*)$ & .003 \\
\hline & \multirow[t]{3}{*}{ Anitpark } & Pazar Yeri & $-4.30000(*)$ & .001 \\
\hline & & Spor Sokak & $-7.03333(*)$ & .000 \\
\hline & & Gaziantep Cad. & $-7.80000(*)$ & .000 \\
\hline & \multirow[t]{2}{*}{ Spor Sokak } & Pazar Yeri & $2.73333(*)$ & .015 \\
\hline & & Anıtpark & $7.03333(*)$ & .000 \\
\hline & \multirow[t]{2}{*}{ Gaziantep Cad. } & Pazar Yeri & $3.50000(*)$ & .003 \\
\hline & & Anıtpark & $7.80000(*)$ & .000 \\
\hline
\end{tabular}


Tablo 2'nin devam1.

\begin{tabular}{|c|c|c|c|c|}
\hline \multirow[t]{8}{*}{ Temmuz } & \multirow[t]{2}{*}{ Pazar Yeri } & Spor Sokak & $-5.96667(*)$ & .003 \\
\hline & & Gaziantep Cad. & $-5.56667(*)$ & .005 \\
\hline & \multirow[t]{2}{*}{ Anitpark } & Spor Sokak & $-8.10000(*)$ & .000 \\
\hline & & Gaziantep Cad. & $-7.70000(*)$ & .001 \\
\hline & \multirow[t]{2}{*}{ Spor Sokak } & Pazar Yeri & $5.96667(*)$ & .003 \\
\hline & & Anitpark & $8.10000(*)$ & .000 \\
\hline & \multirow[t]{2}{*}{ Gaziantep Cad. } & Pazar Yeri & $5.56667(*)$ & .005 \\
\hline & & Anitpark & $7.70000(*)$ & .001 \\
\hline \multirow[t]{4}{*}{ Ağustos } & Pazar Yeri & Anitpark & $3.20000(*)$ & .016 \\
\hline & \multirow[t]{2}{*}{ Anitpark } & Pazar Yeri & $-3.20000(*)$ & .016 \\
\hline & & Gaziantep Cad. & $-3.90000(*)$ & .005 \\
\hline & Gaziantep Cad. & Anitpark & $3.90000(*)$ & .005 \\
\hline \multirow[t]{6}{*}{ Ekim } & \multirow[t]{3}{*}{ Pazar Yeri } & Anitpark & $3.66667(*)$ & .010 \\
\hline & & Spor Sokak & $2.70000(*)$ & .047 \\
\hline & & Gaziantep Cad. & $4.20000(*)$ & .004 \\
\hline & Anitpark & Pazar Yeri & $-3.66667(*)$ & .010 \\
\hline & Spor Sokak & Pazar Yeri & $-2.70000(*)$ & .047 \\
\hline & Gaziantep Cad. & Pazar Yeri & $-4.20000(*)$ & .004 \\
\hline \multirow[t]{4}{*}{ Aralık } & \multirow[t]{2}{*}{ Anıtpark } & Spor Sokak & $-2.70000(*)$ & .012 \\
\hline & & Gaziantep Cad. & $-2.06667(*)$ & .045 \\
\hline & Spor Sokak & Anıtpark & $2.70000(*)$ & .012 \\
\hline & Gaziantep Cad. & Anitpark & $2.06667(*)$ & .045 \\
\hline
\end{tabular}

Tablo 2'ye göre ocak ayında 4, şubat ayında 3, mart ayında 2, nisan ayında 4, mayıs ayında 4, haziran ayında 5, temmuz ayında 4, ağustos ayında 2, ekim ayında 3, aralık ayında 2 adet eşleşme arasındaki fark anlamlı bulunmuş, eylül ve kasım aylarındaki eşleşmelerin hiçbiri anlamlı bulunamamıştır.

Ocak ayında Spor Sokak - Pazar Yeri, Spor Sokak - Anitpark, Gaziantep Caddesi Pazar Yeri ve Gaziantep Caddesi - Anıtpark eşleşmelerinde ortalama gürültü miktarları arasındaki farklar anlamlı bulunmuştur. $\mathrm{Bu}$ eşleşmeler arasında en yüksek ortalama gürültü fark1 Spor Sokak - Anıtpark arasında görülmektedir. Aradaki fark incelendiğinde farkın Spor Sokak açısından pozitif yönlü olduğu dikkati çekmektedir. Buna göre Spor Sokak, Anitpark'a göre ortalama $7.1 \mathrm{~dB}(\mathrm{~A})$ daha gürültülüdür. En az fark ise Gaziantep Caddesi - Pazar Yeri arasında görülmektedir. Buna göre Gaziantep Caddesi, Pazar Yerine göre ortalama $4.03 \mathrm{~dB}(\mathrm{~A})$ daha fazla gürültülüdür.

Şubat ayında sadece Spor Sokak yaya bölgesi ile diğer tüm yaya bölgelerinin ortalama gürültü miktarları arasındaki farklar anlamlı bulunmuştur. Bu eşleşmeler arasında en yüksek ortalama gürültü farkı Spor Sokak - Gaziantep Caddesi arasında görülmektedir. Aradaki fark incelendiğinde farkın Spor Sokak açısından pozitif yönlü olduğu dikkati çekmektedir. Buna göre Spor Sokak, Gaziantep Caddesi'ne göre ortalama 7.8 $\mathrm{dB}(\mathrm{A})$ daha gürültülüdür. En az fark ise Spor Sokak- Anıtpark arasında görülmektedir. Buna göre Spor Sokak, Anıtpark'a göre ortalama $7.13 \mathrm{~dB}(\mathrm{~A})$ daha gürültülüdür. Diğer yaya bölgelerinin birbirleri arasındaki ilişkiler anlamlı bulunamamıştır.

Mart ayında sadece Pazar Yeri yaya bölgesi ile Spor Sokak ve Gaziantep Caddesi yaya bölgelerinin ortalama gürültü miktarları arasındaki farklar anlamlı bulunmuştur. $\mathrm{Bu}$ eşleşmeler arasında en yüksek ortalama gürültü fark1 Pazar Yeri - Spor Sokak arasında görülmektedir. Aradaki fark incelendiğinde farkın Pazar Yeri açısından negatif yönlü olduğu dikkati çekmektedir. Buna göre Pazar Yeri, Spor Sokak'a göre ortalama $8.4 \mathrm{~dB}(\mathrm{~A})$ daha sessizdir. En az fark ise Pazar Yeri - Gaziantep Caddesi arasında görülmektedir. Buna göre Pazar Yeri, 
Gaziantep Caddesi'ne göre ortalama $7 \mathrm{~dB}(\mathrm{~A})$ daha sessizdir. Diğer yaya bölgelerinin birbirleri arasındaki ilişkiler anlamlı bulunamamıştır.

Nisan ayında Pazar Yeri - Anitpark, Spor Sokak - Pazar Yeri, Spor Sokak - Anıtpark ve Gaziantep Caddesi - Anitpark karşılaştırmasında ortalama gürültü miktarları arasındaki farklar anlamlı bulunmuştur. $\mathrm{Bu}$ eşleşmeler arasında en yüksek ortalama gürültü farkı Spor Sokak Anıtpark arasında görülmektedir. Buna göre Spor Sokak, Anıtpark'a göre ortalama 8.8 $\mathrm{dB}(\mathrm{A})$ daha gürültülüdür. En az fark ise Pazar Yeri - Anitpark arasinda görülmektedir. Buna göre Pazar Yeri, Anıtpark'a göre ortalama $3.56 \mathrm{~dB}(\mathrm{~A})$ daha fazla gürültülüdür.

Mayıs ayında Spor Sokak ile Pazar Yeri ve Anitpark, Gaziantep Caddesi ile Pazar Yeri ve Anıtpark karşılaştırmasında ortalama gürültü miktarları arasındaki farklar anlamlı bulunmuştur. $\mathrm{Bu}$ eşleșmeler arasında en yüksek ortalama gürültü farkı Spor Sokak Anıtpark arasında görülmektedir. Buna göre Spor Sokak, Anıtpark'a göre ortalama 7.76 $\mathrm{dB}(\mathrm{A})$ daha gürültülüdür. En az fark ise Gaziantep Caddesi - Pazar Yeri arasında görülmektedir. Buna göre Gaziantep Caddesi, Pazar Yeri'ne göre ortalama 4.40 $\mathrm{dB}(\mathrm{A})$ daha fazla gürültülüdür.

Haziran ayında Pazar Yeri ile Anitpark, Spor Sokak ile Pazar Yeri ve Anitpark, Gaziantep Caddesi ile Pazar Yeri ve Anıtpark karşılaştırmasında ortalama gürültü miktarları arasındaki farklar anlamlı bulunmuştur. $\mathrm{Bu}$ eşleşmeler arasında en yüksek ortalama gürültü farkı Gaziantep Caddesi - Anıtpark arasında görülmektedir. Buna göre Gaziantep Caddesi, Anıtpark'a göre ortalama $7.80 \mathrm{~dB}(\mathrm{~A})$ daha gürültülüdür. En az fark ise Spor Sokak - Pazar Yeri arasinda görülmektedir. Buna göre Spor Sokak, Pazar Yeri'ne göre ortalama 2.73 $\mathrm{dB}(\mathrm{A})$ daha fazla gürültülüdür.

Temmuz ayında Spor Sokak ile Pazar Yeri ve Anitpark, Gaziantep Caddesi ile Pazar Yeri ve Anıtpark karşılaştırmasında ortalama gürültü miktarları arasındaki farklar anlamlı bulunmuştur. Bu eşleşmeler arasında en yüksek ortalama gürültü farkı Spor Sokak - Anıtpark arasında görülmektedir. Buna göre Spor Sokak, Anitpark'a göre ortalama 8.10
$\mathrm{dB}(\mathrm{A})$ daha gürültülüdür. En az fark ise Gaziantep Caddesi - Pazar Yeri arasında görülmektedir. Buna göre Gaziantep Caddesi, Pazar Yeri'ne göre ortalama 5.56 $\mathrm{dB}(\mathrm{A})$ daha fazla gürültülüdür.

Ağustos ayında Pazar Yeri ile Anıtpark ve Gaziantep Caddesi ile Anıtpark eşleşmesinde ortalama gürültü miktarları arasındaki farklar anlamlı bulunmuştur. Bu eşleşmeler arasında en yüksek ortalama gürültü farkı Gaziantep Caddesi - Anıtpark arasında görülmektedir. Buna göre Gaziantep Caddesi, Anıtpark'a göre ortalama $3.9 \mathrm{~dB}(\mathrm{~A})$ daha gürültülüdür. En az fark ise Pazar Yeri - Anıtpark arasında görülmektedir. Buna göre Pazar Yeri, Anıtpark'a göre ortalama $3.2 \mathrm{~dB}(\mathrm{~A})$ daha fazla gürültülüdür.

Ekim ayında sadece Pazar Yeri ile diğer tüm yaya bölgelerinin ortalama gürültü miktarları arasındaki farklar anlamlı bulunmuştur. $\mathrm{Bu}$ eşleşmeler arasında en yüksek ortalama gürültü fark1 Pazar Yeri Gaziantep Caddesi arasında görülmektedir. Buna göre Pazar Yeri, Gaziantep Caddesi'ne göre ortalama $4.2 \mathrm{~dB}(\mathrm{~A})$ daha gürültülüdür. En az fark ise Pazar Yeri - Spor Sokak arasında görülmektedir. Buna göre Pazar Yeri, Spor Sokak'a göre ortalama 2.7 dB(A) daha fazla gürültülüdür. Diğer yaya bölgelerinin birbirleri arasındaki ilişkiler anlamlı bulunamamıştır.

Aralık ayında sadece Anitpark ile Spor Sokak ve Gaziantep Caddesi yaya bölgelerinin ortalama gürültü miktarları arasındaki farklar anlamlı bulunmuştur. $\mathrm{Bu}$ eşleșmeler arasında en yüksek ortalama gürültü farkı Anıtpark - Spor Sokak arasında görülmektedir. Buna göre Anıtpark, Spor Sokak'a göre ortalama $2.7 \mathrm{~dB}(\mathrm{~A})$ daha sessizdir. En az fark ise Anıtpark - Gaziantep Caddesi arasında görülmektedir. Buna göre Anıtpark, Gaziantep Caddesi'ne göre ortalama $2.06 \mathrm{~dB}(\mathrm{~A})$ daha fazla sessizdir.

Tablo 2'deki tüm karşılaştırmalar bir arada incelendiğinde en yüksek farkın nisan ayında ölçüldüğü, buna göre Spor Sokak yaya bölgesinin Anitpark yaya bölgesine göre $8.8 \mathrm{~dB}(\mathrm{~A})$ daha gürültülü olduğu bulunmuştur. En düşük fark ise aralık ayında ölçülmüştür. Buna göre Anıtpark yaya bölgesi, Gaziantep Caddesi yaya bölgesine göre $2.06 \mathrm{~dB}(\mathrm{~A})$ daha sessidir. 
Aylara göre yapılan değerlendirmenin ardından yaya bölgelerinin bulundukları kentsel alan kullanım türüne ile gürültü miktarları arasındaki ilişki incelenmiştir. Buna ilişkin tek yönlü varyans analizi Tablo 3 'te yer almaktadır. Tabloya göre alan kullanımları ile gürültü miktarları arasında ilişki vardır ve açıklanabilmektedir. İlişkinin daha detaylı açılanabilmesi için Tukey testinden faydalanılmıştır. Buna ilişkin sonuçlar ise Tablo 4'te verilmiştir.

Tablo 3. Alan kullanımlarına göre gürültü farkları varyans analizi $(\mathrm{p}<0.05)$

\begin{tabular}{clcc}
\hline Gürültü & & $\begin{array}{c}\text { Kareler } \\
\text { toplamı }\end{array}$ & Önem \\
\hline & Gruplar aras1 & 576,461 &, 000 \\
& Gruplar içi & 1499,182 & \\
& Toplam & 2075,643 & \\
\hline
\end{tabular}

Tablo 4. Alan kullanımlarına göre gürültü farkları Tukey testi sonuçları $(\mathrm{p}<0.05)$

\begin{tabular}{lllrr}
\hline $\begin{array}{l}\text { Bağımlı } \\
\text { değişken }\end{array}$ & Kullanımı & Alan & (J) Alan & \\
& Kullanımı & Ortalama Fark (I-J) & Önem \\
\hline Gürültü & Konut & Açı Yeşil Alan & 1,79861 &, 128 \\
& & Ticaret & $-3,02689\left(^{*}\right)$ &, 001 \\
& \multirow{2}{*}{ Açık Yeşil Alan } & Konut & $-1,79861$ &, 128 \\
& & Ticaret & $-4,82551\left(^{*}\right)$ &, 000 \\
& \multirow{2}{*}{ Ticaret } & Konut & $3,02689\left(^{*}\right)$ &, 001 \\
& & Açı Yeşil Alan & $4,82551(*)$ &, 000 \\
\hline
\end{tabular}

Tablo 4'e göre sadece ticaret alanında bulunan yaya bölgeleri ile konut ve açık yeşil alanda bulunan yaya bölgelerinin gürültü miktarları arasındaki farklar anlamlıdır. $\mathrm{Bu}$ fark Ticaret alanlarındaki yaya bölgelerinde konut alanlarındakine göre yaklaşık $3 \mathrm{~dB}(\mathrm{~A})$, açık ve yeşil alandakine göre ise yaklaşı 5 $\mathrm{dB}(\mathrm{A})$ daha fazladır.

\section{Tartışma ve Sonuç}

Yapılan ölçüm sonuçları karşılaştırıldığında gürültü seviyesinin en yüksek olduğu dönemin yaz mevsimi, en düşük olduğu dönemin ise kış mevsimi olduğu görülmüştür. İlkbahar ve sonbahar mevsimlerinde ise yaz ve kış değerlerinin arasında sonuçlar elde edilmiştir.

Yerli (2012), yaptığı çalıșmada Düzce Kentinde yer alan farkl kentsel alan kullanımlarının gürültü miktarları arasındaki ilişkiyi incelemiş benzer şekilde yaz aylarının en gürültülü, kış aylarının ise en sessiz aylar olduğunu bulmuş, bunun nedenini ise yaz aylarında dış mekan aktivitelerinin çeşitlendiği, dış mekan kullanım sürelerinin ve yoğunluğunun diğer mevsimlere göre arttığına dayandırmıştır.
Tosun ve ark. (2003) Isparta'da ve Tsai ve ark. (2009) Tayvan'ın Tainan bölgesinde yaptıkları çalışmalarda benzer şekilde yaz mevsiminin en gürültü mevsim olduğunu bulmuşlardır.

Aylara ilişkin istatistik analizleri incelendiğinde, yaya bölgeleri karşılaştırmalarının tümünün anlamlı olduğu bir ay bulunmamakla birlikte en fazla anlaml farkın gözlendiği ayın haziran olduğu görülmüştür. En az farkın gözlendiği aylar ise mart, ağustos ve aralık aylarıdır. Hiç bir farkın gözlenmediği aylar ise eylül ve kasım aylarıdır. Yapılan tüm ölçümler içerisinde en gürültülü yaya bölgesinin Gaziantep Caddesi, en sessiz yaya bölgesinin ise Pazar Yeri olduğu görülmüştür. En fazla fark gözlenen karşılaştırma $8.8 \mathrm{~dB}(\mathrm{~A})$ değeri ile Spor Sokak - Anıtpark yaya bölgesi eşleșmesidir.

Çalışma alanlarının mevcut durumları ile bu sonuçlar karşılaştırıldığında yapılan değerlendirmeler ise şu şekildedir: Pazar Yeri yaya bölgesi'nde haftanın belli günleri pazar kurulmakta bunun dişında kalan günlerde alan işlevsizdir. Tosun ve ark. (2003) ve Yerli (2012), konut bölgelerinin en sessiz kentsel alan kullanımına sahip olduğunu bulmuştur. Pazar Yeri yaya bölgesi 
arazi kullanım haritasına göre konut bölgesinde yer almaktadır. Pazarın kurulduğu günlerde gürültü seviyesi kullanıcı yoğunluğu ve pazarcıların sesleri nedeniyle artmaktadır.

Anıtpark yaya bölgesi, 3 tarafi cadde ile çevrili bir kent meydandır ve arazi kullanım haritasına göre açık ve yeşil alan statüsündedir. Yeşil alanların gürültü engellediği yapılan pek çok çalışmada bulunmuştur (Ürgenç, 1998; Aktaş 2002; Erdoğan ve Yazgan 2007; Demir ve ark. 2010). Anıtpark açık ve yeşil alan statüsünde yer almasına rağmen kent meydanı olduğu için içinde ve/veya çevresinde gürültüyü engelleyebilecek bir yeşil perde ya da kitlesel yeşillik bulunmamaktadır. Yerli (2012) ve Demir ve ark. (2010). yaptıkları çalışmalarda gürültünün boşlukta yayılırken azaldığını tespit etmişlerdir. Anıtpark yaya bölgesi 3 tarafı cadde ile çevrili olmasına rağmen gürültü miktarlarının çok yüksek bulunmamasının nedeni de benzer şekilde gürültünün mesafe ile azalması ile açıklanmaktadır.

Spor Sokak ve Gaziantep Caddesi, haftasonları daha fazla olmak üzere kullanıcı yoğunluğunun sürekli olduğu yaya bölgeleridir. Genelde geçiş amaçlı kullanılsa da buluşma, alışveriş, yemek, sokak sergisi gibi etkinliklerin siklıkla gözlendiği alanlardır. Arazi kullanım haritasında bu iki yaya bölgesinin bulunduğu bölgenin alan kullanım türü ticaret olarak tanımlanmıştır. Spor Sokak ve Gaziantep Caddesi'nde gürültü kaynağı insanlar, ticari yapılardan kaynaklanan müzik, sokak satıcıları gibi faktörlerdir. Bitişik nizam yapılaşmanın olduğu yaya bölgelerinde gürültü, zaten dar olan mekanda hapsolmakta ve dağılamamaktadır. Dolayısı ile karşılaştırılan ölçümler incelendiğinde gürültü farklarının Spor Sokak ve Gaziantep Caddesi yaya bölgelerinde daha yüksek olduğu görülmektedir. Sadece bir karşılaştırmada Spor Sokak ve Gaziantep Caddesi arasında istatistiksel olarak anlamlı gürültü farklılığı tespit edilmiştir. $\mathrm{Bu}$ sonuç da bu iki yaya bölgesinin benzer nitelikler taşıdığını göstermektedir. $\mathrm{Bu}$ alanların mevcut fiziksel durumları incelendiğinde de benzerlikler gözlenmektedir. Her iki yaya bölgesinde aynı döşeme malzemesinin kullanıldığı, ortalama
3-4 katlı ve bitişik nizam yapılaşmanın olduğu dikkat çekmektedir.

Düzce kentinde bulunan dört yaya bölgesinde yapılan gürültü ölçümleri sonucunda çeşitli farkların olduğu görülmüştür. Farkların açıklanabilmesi için gürültü değerleri istatistiksel olarak analiz edilmiş ve tespit edilen anlamlı farklara Tukey testi uygulanmıştır. Elde edilen verilere göre gürültü miktarları arasındaki farkların, yaya bölgelerinin farklı alan kullanımlarına sahip olmasından kaynaklandığı sonucunda ulaşılmıştır. Ticaret kullanımının yoğun olduğu yaya bölgelerinde gürültü miktarlarının en yüksek, konut alanı kullanımına sahip yaya bölgelerinde ise gürültü miktarının en az olduğu bulunmuştur.

Gürültü miktarları insan sağlığını tehdit edecek düzeyde değildir ancak çevresel gürültünün uzun vadede ihtiyaçların ve kentsel kullanımların farklılaşması, nüfusun artmas1 gibi etkenler yüzünden artacağ1 öngörülmektedir. Sesin, yayıldı̆̆ şiddetinin azalarak dağılmasını sağlamak amaciyla temas yüzeyinin arttırmasna yönelik çalışmalar yapılmalıdır. $\mathrm{Bu}$ amaca yönelik olarak kullanılacak zemin ve cephe kaplamalarında sesi yansitan değil absorbe edebilen pürüzlü döşeme elemanları kullanılmalıdır. Ayrıca bitkisel materyalin kullanımı da temas yüzeyini arttıracağından gürültünün azaltılmasına yönelik çalışmalarda bitki kullanımına yer verilmelidir.

Sonuç olarak;

- Yaya bölgelerindeki gürültü miktarları mevsimlere göre değerlendirildiğinde en sessiz mevsim kış, en gürültülü mevsim yazdir.

- Aylara göre yapılan değerlendirmelerde iki ay hariç yılın on ayında gürültü miktarları arasındaki ilişki açıklanabilmiştir. "Aylara göre yaya bölgelerinde tespit edilen gürültü miktarları arasındaki farklar anlamlıdır" hipotezi doğrulanmıştır.

- Hepsi yaya bölgesi olmasina rağmen farklı kentsel alan kullanımlarında yer almaları nedeniyle ortaya çıkan gürültü mikarları arasındaki değişimler açıklanabilmiştir. Böylece "yaya bölgelerinde tespit edilen gürültü miktarları arasındaki farklar, yaya bölgelerinin bulunduğu kentsel 
alan kullanımları ile ilişkilidir" hipotezi de doğrulanmıștır.

- Elde edilen değerler, Çevresel Gürültünün Değerlendirilmesi ve Yönetimi Yönetmeliği baz alınarak incelendiğinde, gürültünün özellikle yaz aylarında izin verilen seviyenin üzerine çıktığı, kış aylarında izin verilen seviyenin altına indiği görülmüştür. $\mathrm{Bu}$ anlamda konut bölgelerinde yer alan yaya bölgeleri sessiz, ticaret alanlarında yer alanlar ise gürültülü olarak değerlendirilmiştir. Kentsel alanlarda yaratılacak yaya bölgelerinin gürültüden en az derece etkilenmesi amaciyla bu alanların ticari alanlardan ziyade konut bölgeleri ya da yeşil alanlarda oluşturulması, bu bölgelerde yapılaşmanın bitişik değil ayrık nizamda olmas1, cephe ve zeminde kullanılacak kaplama elemanlarının pürüzlü olması ve bitkisel materyele mutlaka yer verilmesi önerilmektedir.

\section{Kaynaklar}

Aktaş Y. 2002. Kent İçi Alanlarda Bitki Kullanımı ile Gürültü Kontrolü (İstanbul, Maslak - Zincirlikuyu Hattı Örneğinde), Yüksek Lisans Tezi, İstanbul Üniversitesi.

Altunışık R., Coşkun R., Bayraktaroğlu S. ve Yildırım E. 2010. Sosyal Bilimlerde Araştırma Yöntemleri SPSS Uygulamal1, Sakarya Yayıncılık, Sakarya.

Anonim. 2012. TMMOB Fizik Mühendisleri Odas1, A-2 Tipi Mühendislik Akustiği Sertifika Programı, Basılmamış Eğitim Notları.

Bayramoğlu E., Özdemir Ișık B. ve Demirel Ö. 2014. Gürültü Kirliliğginin Kent Parklarına Etkisi ve Çözüm Önerileri: Trabzon Kenti Örneği. İnönü Üniversitesi Sanat ve Tasarım Dergisi, 4(9), 35-42.

Demir Z., Yerli Ö. ve Müderrisoğlu H. 2010. Kentsel Gürültünün Engellenmesinde Bitki Materyali Seçimi, IV. Süs Bitkileri Kongresi Bildiri Kitab1, 20-22 Ekim, Mersin.

Deveci S. 2004. Edirne İlinde Gürültü Düzeylerinin Belirlenerek Gürültü Haritalarının Oluşturulması, Tıpta Uzmanlık Tezi, Trakya Üniversitesi.

Doygun H ve Gurun D. K. 2008. Analysing and Mapping Spatial and Temporal Dynamics of Urban Traffic Noise Pollution: A Case Study in Kahramanmaraş,
Turkey. Environmental Monitoring and Assessment, 142 (1-3), 65-72.

Erdoğan E. ve Yazgan M. 2007. Kentlerde Trafik Gürültüsü Sorununu Azaltmada Peyzaj Mimarlığı Çalışmaları: Ankara Örneği, Tekirdağ Ziraat Fakültesi Dergisi, Tekirdağ, 4 (2), 201-210.

Güremen L. 2012. Amasra Kentinde İlköğretim Okullarında İç ve Dış Çevre Gürültü Koşullarının Değerlendirilmesi, NWSA Engineering Science, 7 (2), 415-435.

Kang, J. ve Zhang M. 2010. Semantic Differential Analysis of the Soundscape in Urban Open Public Spaces. Building and Environment, 45, 150-157.

Ko H. J. Chang S. I. and Lee B. C. 2011. Noise Impact Assessment by Utilizing Noise Map and GIS: A Case Study in the City of Chungju, Republic of Korea. Applied Acoustic, 72 (8), 544-550.

Livera M. D., Priya B., Ramesh A., Suman Rao P. N., Srilakshmi V., Nagapoornima M., Ramakrisnan A. G., Dominic M. and Swarnarekha. 2008. Spectral Analysis of Noise in the Neonantal Intensive Care Unit. Indian Journal of Pediatrics, 75, 217.

Lüleci E. 2000. İzmir'in Bornova İlçe Merkezinde Gürültü Düzeyleri Belirlenerek Gürültü Haritalarının Oluşturulması, Tıpta Uzmanlık Tezi, Ege Üniversitesi, İzmir.

Özyonar F. ve Peker İ. 2008. Sivas Kent Merkezindeki Çevresel Gürültü Kirliliğinin Araştırılması, Ekoloji Dergisi, 18 (69), 7075.

Pathak V., Tripathı B. D. ve Mishra V. K. 2008. Evaluation of Traffic Noise Pollution and Attitudes of Exposed Individuals in Working Place. Atmospheric Environment, 42, 3892-3898.

Salomons E. M. ve Pont M. B. 2012. Urban Traffic Noise and the Relation to Urban Density, Form, and Traffic Elasticity. Landscape Urban Plannig, 108(1), 2-16.

Szeremeta B. ve Zannin P. H. T. 2008. Analysis and Evaluation of Soundscapes in Public Parks through Interviews and Measurement of Noise. Science Total Environment, 407(24), 6143-6149.

Şahin G. Y. 2007. Trabzon Havaliman1 Gürültüsü ve İnsan Üzerindeki Etkileri, Yüksek Lisans Tezi, Karadeniz Teknik Üniversitesi, Trabzon. 
Şişman E. E. ve Uyguner B. 2009. Tekirdağ Kent Merkezinde Kullanıcıların Yaya Bölgeleri Hakkındaki Görüşlerinin Belirlenmesi. Süleyman Demirel Üniversitesi Orman Fakültesi Dergisi, A(2), 134-146.

Tosun I., Avşar Y., Sevindir H.C. ve Beyhan M. 2003. Effect of Traffic and Industrial Activities on Noise in Isparta, Süleyman Demirel University, Science Institute Journal, Isparta, VII. 70-79.

Tsai K.T., Lin M.D. and Chen Y.H. 2009. Noise Mapping in Urban Environments: A Taiwan Study, Applied Acoustic, 70, 964972.

Ural A. ve Kıliç İ. 2005. Bilimsel Araştırma Süreci ve SPSS ile Veri Analizi, Detay Yayıncilık, Ankara.

Ural, E. 2008. Çevre Sorunları ve Çevre Hukuku, Çevrenin Kitabı. Türkiye Çevre vakfi Yayını, Ankara.

Uslu G., Koçer N., Arslanoğlu H. ve Hanay Ö. 2007. Elazı̆̆ İlindeki Gürültü Kirliliğine Karayolu Trafiğinin Etkisi, TMMOB Çevre Mühendisleri Odas1 7. Ulusal Çevre Mühendisliği Kongresi, İzmir.

Ürgenç S. İ. 1998. Genel Plantasyon ve Ağaçlandırma Tekniği, İstanbul Üniversitesi Orman Fakültesi, Üniversite Yayın No: 3997, Fakülte Yayın No: 444, ISBN: $975-$ 404-443-0, İstanbul.

Yerli Ö. 2012. Kentsel Alan Kullanım Kaynaklı Gürültünün Düzce Kenti Örneğinde İrdelenmesi. Düzce Üniversitesi Fen Bilimleri Enstitüsü Peyzaj Mimarlığ Anabilim Dalı, Doktora Tezi, Düzce.

Yerli Ö., Aşıkkutlu H. S., Demir Z. ve Müderrisoğlu H. 2012. Kamp ve Pikniğe Dayal1 Rekreasyon Gürültüsünün Değerlendirilmesi: Yedigöller Milli Park1 Örneği, I. Rekreasyon Araştırmaları Kongresi, 12-15 Nisan,Antalya.

Yerli Ö. ve Demir Z. 2015. Otoban Gürültüsünün Dinlenme Tesislerine Etkisi: İstanbul-Ankara Otoyolu Örneği, Balıkesir Üniversitesi Fen Bilimleri Enstitüsü Dergisi, 17(1), 1-15.

URL1- http://gurultu.cevreorman.gov.tr/ gurultu/Files/Mevzuat/Y\%C3\%B6netmelikle r/T\%C3\%BCrk\%C3\%A7e/\%C3\%87GDYYDe\%C4\%9Fi\%C5\%9Fikli\%C4\%9Fin\%20i\% C5\%9Flenmi\%C5\%9F\%20hali.pdf, 2016.

URL2- www.google.com/maps, 2016. 